811.163.41'373.422

811.163.41'37

811.163.41'374

https://doi.org/10.18485/sj.2021.26.1.31

МИЛЕНА М. ЈАКИТ ШИМШИЋ*

Институт за српски језик САНУ

Београд
Оригинални научни рад

Примљен: 13. 10. 2020.

Прихваћен: 12.1.2021.

\title{
АНТОНИМИЈА ПРЕКО ГРАНИЦА ВРСТА РЕЧИ У ТЕСТУ КОНТРОЛИСАНИХ АСОЦИЈАЦИЈА*
}

Традиционална лингвистика*** сматра да се антонимија успоставља међу јединицама исте врсте речи. Ипак, бројни докази из корпусних истраживања потврђују међукатегоријалну антонимију, иако се наводи да није потврђена у асоцијативним тестовима. У раду приказујемо случајеве када изворни говорници српског језика у тесту контролисаних асоцијација као антониме придева не наводе (праве) придеве. Показало се да се у пољима придевских стимулуса најчешће јављају глаголски придеви и глаголски прилози, а нешто ређе непридевске именске речи. Већи број непридевских антонима јавља се у пољима придева насталих од глаголских придева, него у пољима правих придева. Потенцијални разлози ређе леже у постојању лексичких празнина или у хомографији са јединицама других врста речи, а чешће у могућности да се исти фрагмент стварности кодира помоћу различитих врста речи или у енкапсулацији значења именице, са којом дати придев често колоцира. Ипак, најчешће је међукатегоријална антонимија само привидна, будући да трпни придеви конверзијом често постају прави придеви, те је заправо реч о богаћењу система придева. Упоређивањем типа дефиниције која је приписана придевима насталим од глаголских придева примећујемо да

*mmjakic@gmail.com

** Овај рад финансирало је Министарство просвете, науке и технолошког развоја Републике Србије према Уговору број 451-03-68/2020-14/200174 који је склопљен са Институтом за српски језик САНУ.

**** Материјал за истраживање прикупљан је у склопу дисертације Придевска антонимија у речнику, контексту и когнитивном систему (Јакић 2016а). 
испитивани речник (РС ) не пресликава увек језичка знања изворних говорника у погледу степена лексикализације. Прави представници међукатегоријалне антонимије у нашој грађи сразмерно су ретки (1,3\%), што значи да антонимија јесте однос који се најчешће успоставља између јединица исте врсте речи.

Кључне речи: антоним, значењска супротност, асоцијативни речник, конверзија, лексикализација, лексикографска обрада, трпни придев, изворни говорник, квантитативна анализа, парадигматски/синтагматски лексички однос.

\section{1. УВОД}

Традиционално схватање Де Сосирове поделе на синтагматске и парадигматске односе (Сосир 1989) подразумева да у синтагматске односе ступају лексеме које припадају различитим врстама речи, а у парадигматске, оне које припадају истој врсти речи (Кристал 1985). Ипак, поједини аутори наводе да ова два типа односа није увек лако разликовати (Марфи 2003: 8), додали бисмо макар формално, што би се могло поткрепити различитим случајевима синтагматског комбиновања две лексеме исте категоријалне припадности (нпр. прилошка синтагма сачињена од два прилога: веома лепо или атрибутивна функција именице као у змија отровница), као и различитим случајевима када се у реченицама доводе у парадигматски значењски однос лексеме које не припадају истој категорији (нпр. у реченици „У заливу је било ледено, а на отвореном мору бара.”, прилог ледено и именица бара су у односу значењске супротности, јер је бара употребљено у значењу топло).

Тако се на пример однос антонимије ${ }^{1}$ убраја међу парадигматске лексичке односе, те поједини аутори имплицитно, наводећи примере парова антонима (Лајонс 1977: 271; Палмер 1979: 79), а неки и експлицитно, као један од услова за успостављање односа антонимије наводе припадност истој врсти речи. Неки то формулишу кроз припадност истој лексичко-семантичкој групи (Гортан Премк 2004: 146), а други кроз постојање исте архисеме, или заједничког хиперонима (Драгићевић 2007: 280).

Међутим, примећено је да и лексеме које припадају различитим врстама речи могу у одређеним контекстима ступити у однос антонимије (Фелбаум 1995: 289; Бојева Омелечко и др. 2018). Досадашња истраживања углавном су утврђивала овај феномен на материјалу добијеном из корпуса, проналазећи примере овакве употребе језичких јединица (нпр. rain - dry у реченици: „Ноћ је била испуњена мирисом кише на сувој земљи.” (Бојева Омелечко и др. 2018: 116)). Тако К. Фелбаум, на материјалу енглеског језика, увиђа да се семантички супротстављени концепти јављају заједно у реченици независно од класе речи

\footnotetext{
${ }^{1}$ Термин антонимија користи се у ширем смислу, да означи све врсте супротности, а не само најбоље представнике (исп. Јакић Шимшић/Весић Павловић 2020).
} 
којој припадају (Фелбаум 1995: 289, 297). На пример, на основу асоцијативних норми, придеви wet и $d r y$ [= мокар и сув] чврсто су асоцијативно повезани, међутим, у Брауновом корпусу (Brown Corpus) придев wet подједнако често се јавља у реченици са глаголом $d r y$ [= осушити], као и са придевом $d r y$. Фелбаумова, међутим, истиче да феномен примећен у корпусу, да антоними не морају припадати истој врсти речи, није потврђен у асоцијативним тестовима, и притом наводи да испитаници у асоцијативним тестовима теже да одговоре истом синтаксичком класом, али и истим флективним наставком као што је стимулус (Исто: 293). Други аутори такође проналазе примере међукатегоријалне антонимије и наводе да уколико између два својства постоји контраст у објективној реалности, он неће нестати услед чињенице да је у језику нешто кодирано помоћу различитих врста речи (Бојева Омелечко и др. 2018: 114).

Узимајући у обзир структуру енглеског језика, претпоставили смо да су налази К. Фелбаум повезани са његовом коренском структуром, као и са продуктивношћу конверзије као начина творбе. Конверзија се дефинише као творбени процес у коме се од основне речи добија реч која има другачије лексичко и граматичко значење, промењена „мање морфолошка, а више синтактичка" обележја (Тафра 1998: 350), или као постанак нове речи преласком из једне у другу врсту „без посебнога додавања творбених елемената” (Бабић 1991). Стога непостојање формалне разлике између мотивне и мотивисане речи, поготово у ситуацији изолованог приказивања, онемогућава поуздано утврђивање врсте речи асоцијата. За разлику од тога, флективни језици, попут српског, чешће користе творбене процесе у којима је настанак нове врсте речи најчешће маркиран посебним творбеним елементом. Стога је и при одсуству конктекста могуће уочити међукатегоријалну супротност. Са друге стране, ниже у тексту, видећемо да се и у флективним језицима конверзија понекад користи за добијање канонског облика мотивисане речи (нпр. облик смотан од трпног придева глагола смотати, у атрибутској позицији добија категорију падежа или компарације: смотаном, смотанији). У том случају, лексиколошки критеријум се показује као најпоузданији за одређивања врсте речи, јер „нове ријечи ступају у нове синонимне и антонимне односе, што може бити провјера је ли ријеч о конверзији” (Тафра 1998: 352).

У овом раду доносимо грађу добијену из истраживања спроведеног помоћу теста контролисаних асоцијација, са изворним говорницима српског језика, а циљ нам је да на материјалу флективног језика, какав је српски, укажемо на различите случајеве када придеви ступају у однос значењске супротности са јединицама које припадају другој врсти речи. 


\section{2. ЦИљЕВИ ИСТРАЖИВАњА}

Узевши у обзир досадашње налазе, основни циљ овог истраживања јесте да укажемо на случајеве када изворни говорници као значењску супротност придева наводе одговоре који припадају другој врсти речи. Покушаћемо да одговоримо на следећа питања:

2.1. Које врсте речи се најчешће јављају као значењска супротност придева?

2.2. Код којих придева изворни говорници успостављају однос значењске супротности са јединицама других врста речи?

2.3. Због чега долази до успостављања односа значењске супротности међу јединицама различитих врста речи?

\section{3. МЕТОДОЛОГИЈА ИСТРАЖИВАЬА}

У истраживању је спроведен тест контролисаних асоцијација, у коме су испитаници наводили антониме задатих стимулуса. Њихови одговори морфолошки су анотирани, а статус одредница проверен у једнотомном описном Речнику српскога језика (у даљем тексту РСЈ).

\section{1. Стимулуси и испитаници}

У истраживању је приказано 394 стимулуса, од чега је 42 идентично са глаголским облицима (32 са трпним придевом, 6 са радним придевом и 4 са глаголским прилозима), а неки од њих нису евидентирани као придевске одреднице у РСЈ. Учествовало је 158 испитаника, изворних говорника српског језика, старости између 18 и 55 година, оба пола.

\section{2. Формирање Асоцијативног речника придевских антонима српског језика}

Испитаници су за сваки од 394 понуђена стимулуса наводили најмање један, а највише три антонима. На основу њихових одговора формиран је Асоцијативни речник придевских антонима српског језика (у даљем тексту: АРПАСЈ) (Јакић Шимшић/Шева, у припреми), који садржи 394 асоцијативна-антонимска поља (в. Слику 1), а укупан број добијених асоцијата-антонима износи 71.358. 
Слика 1. Асоцијативно-антонимско поље придева храбар.

\begin{tabular}{|llll|}
\hline храбар & 66 & 8 & $\mathbf{7 4}$ \\
\hline клашљив & 38 & 3 & $\mathbf{4 1}$ \\
\hline кукавица & 33 & 1 & $\mathbf{3 4}$ \\
\hline кукавички & 8 & 3 & $\mathbf{8}$ \\
\hline уплашен & 2 & $\mathbf{5}$ \\
\hline слаб & 4 & 1 & $\mathbf{4}$ \\
\hline страшљив & 1 & $\mathbf{2}$ \\
\hline слабашан & 2 & $\mathbf{2}$ \\
\hline бојажљив & 1 & 1 & $\mathbf{2}$ \\
\hline чврст & 1 & & $\mathbf{1}$ \\
\hline несмео & & 1 & $\mathbf{1}$ \\
\hline неодважан & 1 & & $\mathbf{1}$ \\
\hline кукавичји & & 1 & $\mathbf{1}$ \\
\hline застрашив & 1 & $\mathbf{1}$ \\
\hline застрашен & 1 & $\mathbf{1}$ \\
\hline
\end{tabular}

Лево - придев-стимулус „храбар”; десно - асоцијати-антоними поређани према опадајућем рангу асоцијативне фреквенције; прва, друга и трећа колона са асоцијативним фреквенцијама - број испитаника који су дати асоцијат-антоним навели на првом, другом и трећем месту; четврта колона - збир асоцијативних фреквенција за дати асоцијат-антоним на било којој од позиција. У истраживању су коришћени збирни подаци о асоцијативним фреквенцијама (четврта колона).

\section{3. Анотирање одговора испитаника}

У сваком асоцијативном-антонимском пољу мали број одговора има високу асоцијативну фреквенцију, док је велики број хапакса² (што је у складу са општеважећим Зипфовим законом, Зипф 1949). Релевантност одговора пак директно је пропорционална броју испитаника који су навели дати одговор. Стога смо само одговорима које су навела барем три испитаника (таквих је било 64.276, односно 1.363 лексема) приписали врсту речи, бележећи и информацију да су неки придеви идентични са облицима глаголских прилога и придева, чиме је анализирано 90\% свих асоцијата-антонима добијених у АРПАСЈ.

\footnotetext{
${ }^{2}$ Под хапаксом овде подразумевамо одговор који наводи само један испитаник.
} 


\section{4. Речник: РСЈ}

У истраживању је коришћен Речник српскога језика (РСJ), како бисмо стекли увид којим одредницама-стимулусима је додељен статус лексикализованог придева и осамостаљење од одговарајућег глагола. Ослонили смо се на члан 302, у Упутствима за израду Речника САНУ (принципи којима су се руководили и аутори РСJ), који се бави обрадом глаголских придева:

„Трпне глаголске придеве треба давати као засебне одреднице само кад су постали прави придеви $[. .$.$] а постали су прави придеви ако се могу дефинисати тако да дефи-$ ниција не буде с каквим трпним придевом [...] Ако се значење није удаљило од глагола, треба дати граматичку дефиницију [...] ако се значење удаљило, даје се нормална, описна дефиниција [...]”. (Упутства РСАНУ)

Статус одреднице, тј. степен њене лексикализације, лексикографски се маркира успостављањем одреднице (нпр. за придеве поломљен, насељен, обучен, ошамућен није успостављена одредница), а након тога типом дефиниције (тј. да ли је примарно значење описано типском граматичком дефиницијом, као у: скучен, -а, -о 1. трп прид. од скучити (се), или правом придевском дефиницијом као у замишљен, -а, -о утонуо у мисли; који постоји само у мислима $[. .$.$] ; компликован, -а, -о сложен, заплетен, замршен).$

\section{4. РЕЗУЛТАТИ ИСТРАЖИВАЬА}

Број непридевских асоцијативних-антонимских одговора за 394 испитивана стимулуса, није занемарљив (11,8\% на нивоу појединачних речи, а 19,1\% на нивоу различитих лексема).

\section{1. Асоцијати}

(1) Квантитативном анализом показано је да међу „непридевским”з антонимима придева постоји апсолутна предоминација трпних придева и према броју стимулуса у чијим се асоцијативним-антонимским пољима јављају (153), и према броју лексема које су се јавиле као асоцијати-антоними (221), и према њиховој збирној асоцијативној фреквенцији (5.235, односно 70\% свих непридевских асоцијата-антонима). Другим речима, на основу знања изворних говорника можемо закључити да се придевски систем српског језика често употпуњава помоћу трпних придева (нпр. ограничен, расположен, опуштен) (в. Слику 2).

\footnotetext{
${ }^{3}$ Реч „непридевски” за сада је стављена под наводнике, а нешто касније размотрићемо да ли се заиста у свим случајевима ради о „непридевима”.
} 
Слика 2. Анализа непридевских асоцијата-антонима за стимулусе из АРПАСЈ

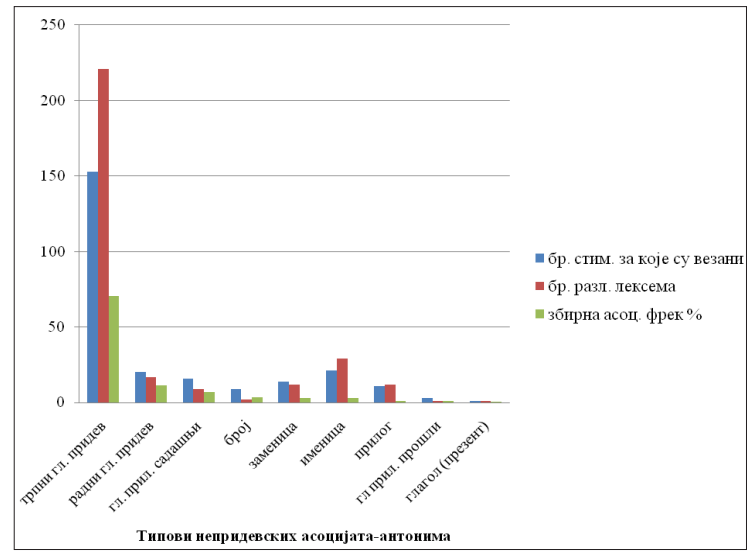

Приказ различитих категорија „непридевских” асоцијата-антонима за придеве-стимулусе из АРПАСЈ (Јакић Шимшић/Шева, у припреми) према броју стимулуса у чијим се асоцијативним-антонимским пољима јављају (на графикону: бр.(ој) стим.(улуса) за које су везани), према броју лексема које припадају датој непридевској категорији (бр.(ој) разл.(ичитих) лексема) и према проценту испитаника који су дату категорију навели као асоцијат-антоним придева (збирна асоц. (ијативна) фрек.(венција) \%).

На другом месту налазе се радни придеви (11\%), али се они везују за мањи број стимулуса (20), и представљени су далеко мањим бројем различитих лексема у односу на трпне придеве (17) (нпр. прошли, незрео, заостао, смео). Након тога следе лексеме настале од глаголских прилога (7,6\%), које се везују за нешто мањи број стимулуса (18), а број лексема (10) је прилично ограничен (нпр. неодговарајући, збуғујући, разарајући, отежавајући, бивши). Када су у питању именске речи, примећујемо да се у систему антонима придева налази број ,један”, и то готово увек у облику „први”, ${ }^{4}$ и везује се за 9 стимулуса (нпр. завршни, средишњи), али му је асоцијативна фреквенција у појединим пољима изузетно висока (последњи - први (97\% испитаника)). Број заменичких лексема износи 12 (нпр. свој, наш, свачији), оне се везују за 11 стимулуса, укупна асоцијативна фреквенција није велика, али захвата значајан део неких поља (нпр. $m y \hbar-c в о j ~(33,5 \%))$. Број именичких лексема пак нешто је већи, али се везује за већи број стимулуса, те им је учешће у појединим асоцијативним-антонимским пољима од мањег значаја, осим у случају придева храбар где се именица кукавица јавила у $26,5 \%$ случајева. Одговоре за које није јасно да ли су прилози или придеви, сматрали смо прилозима, али чак и тада њихов број

${ }^{4}$ У асоцијативним пољима јавио се и број два у облику „други”, али у овом истраживању није укључен у анализу, јер му је асоцијативна фреквенција по пољима била мања од 3 . 
није велики, тј. јављају се у 11 асоцијативних поља и то са свега 12 лексема (нпр. ретко, мало, кукавички), а збирна асоцијативна фреквенција у свим пољима је готово занемарљива $(1,2 \%)$. Глагол у облику презента последица је погрешно протумачене врсте речи стимулуса, тј. за придев-стимулус касни 4 испитаника навела су асоцијат-антоним жури.

\section{2. Стимулуси}

Одговарајући на питање (2) код којих придева се јавио већи број непридевских асоцијата-антонима, стимулусе смо класификовали на праве придеве и придеве настале од глаголских облика. Примећујемо да се већи број непридевских асоцијата-антонима јавио код стимулуса насталих од облика глаголских придева и прилога, него код правих придева (в. Слику 3).

Слика 3. Поређење асоц. поља стимулуса из АРПАСЈ

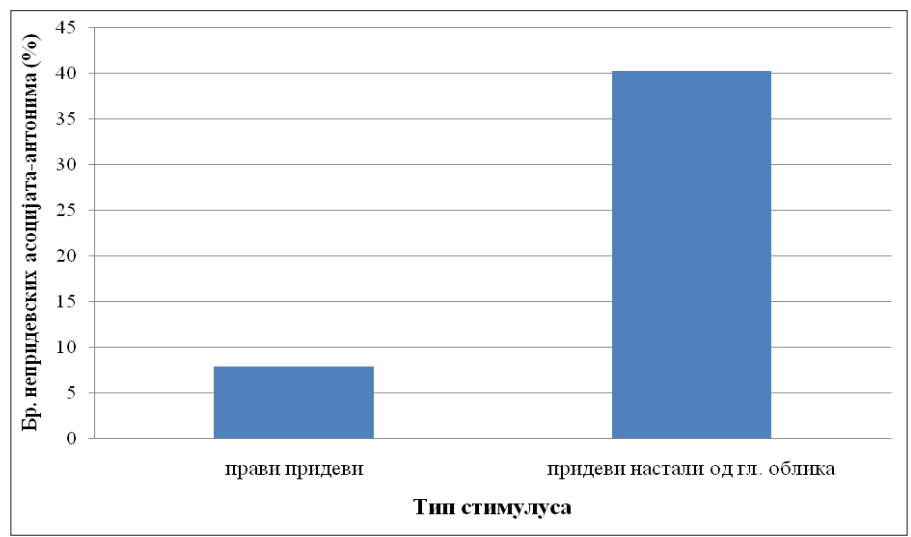

Приказ удела „непридевских” асоцијата-антонима у асоцијативним пољима АРПАСЈ (Јакић Шимшић/Шева, у припреми) стимулуса који су прави придеви и стимулуса који су настали од глаголских облика (на графику: придеви настали од гл.(аголских) обл.(ика)).

Разложивши пак стимулусе настале од глаголских облика, највећи број „непридевских” асоцијата-антонима налази се у пољима трпних придева-стимулуса (42\%), при чему су сви такви асоцијати-антоними такође трпни придеви, па затим у пољима глаголских прилога (33,5\%), а потом у пољима радних придева (24,5\%) (в. Слику 4). 
Слика 4. Поређење асоц. поља придевских стимулуса у АРПАСЈ, насталих од глаголских облика

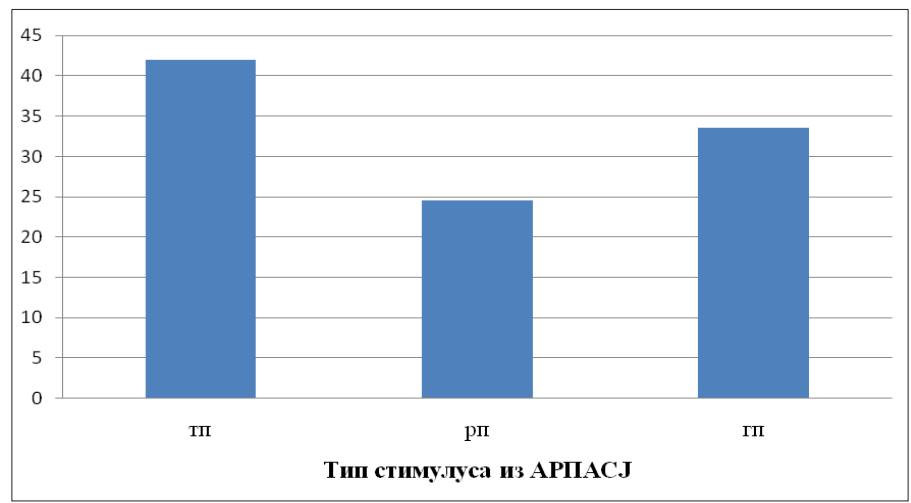

Приказ удела непридевских асоцијата-антонима у асоцијативним пољима из АРПАСЈ (Јакић Шимшић/Шева, у припреми) стимулуса који су настали од трпних придева (тп), радних придева (рп) и глаголских прилога (гп).

Како бисмо проверили да ли се степен лексикализације придева насталих од глаголских придева, који је забележен у РСЈ (на основу анализе типа дефиниције) поклапа са подацима добијеним од изворних говорника, спровели смо додатну анализу стимулуса насталих од глаголских придева. Од 32 стимулуса настала од трпних придева 13 није добило засебну одредницу у РСЈ (нпр. закрпљен, играни, ошамућен, узбућен), за 13 је у примарној дефиницији наведено да је то трпни придев од одговарајућег глагола, док су остале дефиниције придевске (нпр. завијен, заузет, изгубљен, повучен, сложен), а 6 је обрађено само придевским дефиницијама (нпр. замишљен, компликован, насмејан, умерен). Од 6 стимулуса насталих од радних придева за 3 је у примарној дефиницији наведено да је то радни придев од одговарајућег глагола (застарео, зрео, одрастао), а 3 су обрађена помоћу придевских дефиниција (врео, прошли, труо).

Резултати показују да се као асоцијати-антоними најчешће јављају прави придеви, и то код свих типова глаголских придева (и код оних којима је у РСЈ дат статус правих придева, тп: $61,6 \%$; рп: 76,3\%, и код оних где се сугерише несамосталност од одговарајућег глагола, тп: $50 \%$; рп: 70\%, и код оних за које није успостављена придевска одредница, тп: 53\%) (в. Слику 5). 
Слика 5. Поређење степена лексикализације гл. придева из АРПАСЈ

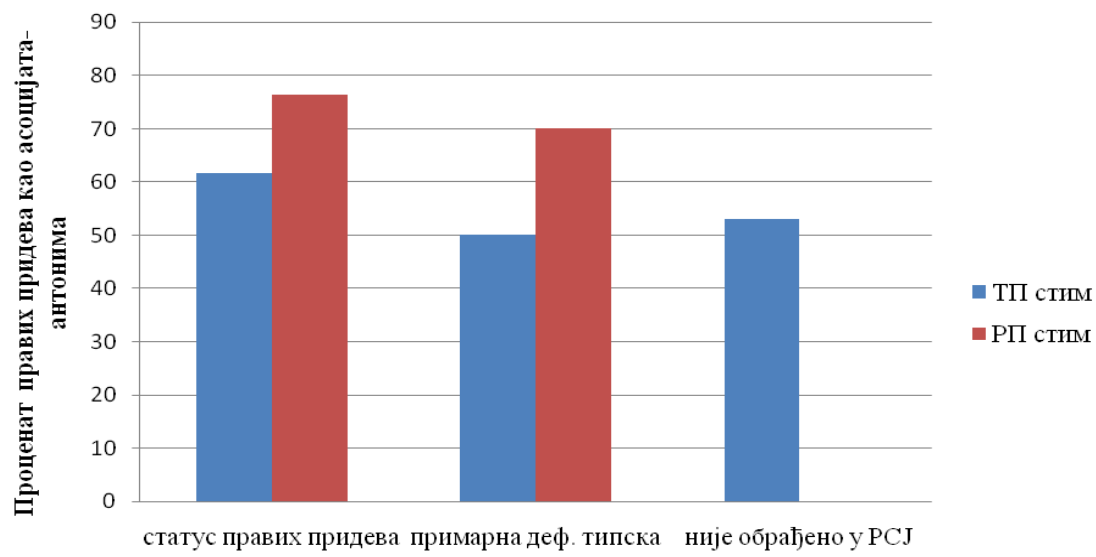

Тиі деф. у РСJ

Поређење степена лексикализације придевских стимулуса насталих од глаголских придева, на основу две мере: броја асоцијата-антонима у АРПАСЈ (Јакић Шимшић/Шева, у припреми) који припадају класи правих придева, и анализе типова приписаних дефиниција у РСЈ. (ТП стим = придеви-стимулуси настали од трпних придева; РП стим = придеви-стимулуси настали од радних придева)

\section{3. Разлози}

Да би се подробније одговорило на питање о (3) потенцијалним разлозима појаве непридевских одговора у асоцијативним-антонимским пољима придева, неопходно би било спровести детаљну семантичку анализу стимулуса и њихових придевских и непридевских асоцијата-антонима. Но, будући да би таква анализа далеко превазишла обим и циљеве овог рада, задржаћемо се само на односу између „непридевске” речи и одговарајућег стимулуса. Класификација разлога коју предлажемо стога је сасвим условна и сводимо је на неколико најчешћих случајева.

\subsection{1. Конверзија}

Најчешћи случај јесте навођење асоцијата-антонима који изворно припадају другој врсти речи (глаголима), али су у асоцијативном-антонимском пољу употребљене као прави придев, тј. процесом конверзије оне су и постале придеви (89,2\% свих „непридевских” асоцијата-антонима). ${ }^{5}$

${ }^{5}$ Према мишљењу неких аутора тешко је рећи да ли трпни придеви постају придеви, или су то већ и били (Клајн 2003). 
Прелазак у придевску врсту речи илустрован је великим бројем придева који су настали од глаголских придева и прилога (нпр. прост - сложен, нервозан-смирен, го - обучен, садашњи - прошли, дечији -одрасли, претходни - следећu). Најбољи показатељ лексикализације ових придева управо је велики број испитаника који наводе дату лексему као супротност задатих стимулуса који су прави придеви (53\%-96\% испитаника). Стога ове случајеве и нећемо рачунати као непридевске асоцијате. Сви остали разлози укупно захватају $1,3 \%$ испитиваних асоцијата-антонима.

\subsection{2. Употреба лексеме у придевском значењу}

Употреба датог непридевског асоцијата-антонима у придевском значењу јавља се у $51,5 \%$ случајева. На пример, семантичку класу придева-стимулуса који означавају позицију или редослед (нпр. задњи, крајњи, стражњи) изворни говорници често доводе у однос значењске супротности са редним бројем $n р в и$, употребљеним у придевском значењу почетни, предњи, те га наводе као асоцијат-антоним (у паровима: задњи - први, крајњи - први, стражњи-први). Неколико испитаника употребило га је и у значењу главни, у пару: резервни - први, помишљајући вероватно на колокације типа резервна постава - прва постава или сл. ${ }^{6}$

\subsubsection{1. БЛИСКОСТ ЛЕКСИЧКОГ ЗНАЧЕЊА ЗА РАЗЛИЧИТЕ ВРСТЕ РЕЧИ}

Семантичку класу придева-стимулуса који означавају припадност (нпр. туђ, иностран, светски, заједнички, приватан, лични), испитаници често доводе у однос значењске супротности са присвојним заменицама, те су се у нашој грађи јавили парови антонима туђ - свој, туђ - нам, туђ -мој, туђнечији, иностран-наш, заједнички -мој, заједнички - свој, лични - свачији, приватан-свачији, светски-наш, стран-наш).

\subsection{3. Кодирање истог фрагмента стварности помоћу различитих врста речи}

Као и у корпусним истраживањима на енглеском језику (Бојева Омелечко и др. 2018), и у нашој грађи приметили смо да се исти фрагмент стварности може описати помоћу више од једне врсте речи. Овај разлог јавио се у нашој грађи у 19\% случајева (нпр. за придев мат испитаници наводе именицу сjaj, која је у творбеној вези са придевом сјајан; или цеео - пола/део; читав - део,

${ }^{6}$ Могло би се дискутовати да ли и овај разлог треба сматрати кодирањем истог фрагмента стварности помоћу различитих врста речи, али до сада се овим термином у литератури називао случај када постоји творбена веза међу јединицама различитих врста речи, али не и случајеви блискости значења различитих врста речи као у пр. 
уместо придевских антонима: половичан, делимичан; далек - близу, ${ }^{7}$ уместо: близак).

\subsubsection{1. ХОМОФОРМЕ}

Неколико случајева није било лако класификовати, будући да смо се питали због чега су испитаници за придевске стимулусе, и поред постојања антонимских придева наводили прилоге, али могуће је да када се као стимулуси презентују индеклинабилни придеви (мат, тазе, таман $\left.{ }^{8}\right)(6,3 \%)$, тј. такви канонски облици који не сугеришу о ком роду се ради, то може утицати на продукцију родно неутралног средњег рода придева, који је хомоформан са одговарајућим прилогом. Тако су одговори за ове стимулусе били: мат сјајно, тазе - бајато/старо, таман - тесно.

\subsection{4. Енкапсулација значења}

Једну групу примера чине придеви-стимулуси који често колоцирају са одређеним именицама, те при помену датог придева испитаници помишљају на колокацију датог придева са именицом, и као антониме наводе именице које енкапсулирају, односно сажимају придевско значење особине са именичким значењем (9,3\% случајева). У неким случајевима именичко значење односи се на особу: штедљив - трошаиија; шкрт - расипник; скроман-хвалисаваи; дружељубив-самотьак; грешан-светаи; марљив-нерадник; веран-варалица; имућан-сиромах; одрастао - дете. У другим случајевима то могу бити и именице са другим значењима: нпр. документарни - комедија, где испитаник помишља на колокацију „документарни филм”, или златан - бижутерија, где испитаник помишља на колокацију ,златан накит”.

\subsubsection{1. ЛЕКСИЧКА ПРАЗНИНА}

Пример храбар - кукавица такође илуструје енкапсулацију значења, с тим што бисмо рекли да се ту ради и о лексичкој празнини у систему придева (5\%), будући да не постоји придев који би означио супротност од храбар. Наиме, да би неко био храбар неопходно је да осећа страх, те придев плашљив не представља прави семантички антоним придева храбар (о овом питању и

${ }^{7}$ Рекли бисмо да код придева близак постоји и спецификација значења, тј. да означава метафоричну духовну односно родбинску блискост, док се просторна блискост пре исказује прилогом близу.

${ }^{8}$ Придев таман, задат је као деклинабилни придев чији би антоним био светао, али један део испитаника схватио га је као придев који би се могао употребити у реченици „Ове ципеле су ми таман." 
разлозима навођења појединих асоцијата-антонима у пољу придева храбар исп. Јакић 2016а: 238-243 и Јакић 2016б: 149).

\subsection{5. Хомографија и хомоформе}

У неким случајевима навођење непридевских одговора указује на хомографију или хомоформу у стимулуса са другом врстом речи (8,2\%) (нпр. стимулус полаган поред значења: 1) не сувише брз и 2) не сувише тежак, за која везујемо највећи број одговора, изазвао је и одговоре неположен, подучаван, подизан, нерешен, паднут, који се могу везати за облик настао од глагола полагати у значењима полагати испит или полагати неки предмет на какву повриину). Други такви примери јавили су се услед погрешно схваћене врсте речи стимулуса (нпр. придев свет део испитаника схватио је као именицу, па су наводили асоцијате-антониме: космос, универзум, појединац, човек; за придев мат наводили су одговоре: шах, почетак; за придев скуп наводили су: појединац, јединка, појединачно; за придев кукавички -храбро, за десни кости, за го-статива, за раднички - црвена звезда).

\subsubsection{1. ПОГРЕШНО ПРОЧИТАН СТИМУЛУС}

Мањи број случајева јавио се услед тога што су испитаници погрешно прочитали стимулус (0,6\%). ${ }^{9}$ Пример за ово је да су испитаници стимулус крут прочитали као круг, те су као антоним навели именицу квадрат.

\section{5. ДИСКУСИЈА И ЗАКЉУЧНА РАЗМАТРАЬА}

5.1. Резимирајући налазе закључујемо да се као асоцијати-антоними придева најчешће јављају прави придеви (88\%), без обзира на тип стимулуса (прави придеви или придеви настали од глаголских облика). Ипак, не тако мали број одговора представљају придеви настали од глаголских придева и прилога, док је знатно мање непридевских именских речи.

5.2. Придеви настали од глаголских облика у своје поље привлаче већи број асоцијата-антонима који нису прави придеви, али будући да преовлађују прави придевски одговори, сматрамо да није доведена у питање њихова придевска лексикализација. Поред тога, велики број трпних придева у асоцијативном-антонимском пољу стимулуса који су и сами настали од трпних придева у складу је са налазом К. Фелбаум да испитаници у асоцијативним

${ }^{9}$ У делу асоцијативног-антонимског поља који смо испитивали, број оваквих случајева је мали, за разлику од дела асоцијативног поља који смо изоставили из анализе (одговори које су наводили 1 или 2 испитаника). 
тестовима настоје да наводе одговоре са истим наставком као што је стимулус (Фелбаум 1995: 293). ${ }^{10}$

Склоност ка привлачењу непридевских одговора имају и поједине семантичке класе придева, које су блиске значењима других врста речи (нпр. придеви последњи, средишьи, завршни, који означавају позицију или редослед, лако успостављају однос антонимије са бројем „први” у придевским значењима, док придеви туђ, стран, заједнички, из семантичке класе припадности/присвајања, успостављају однос антонимије са присвојним заменицама свој, ${ }^{11}$ наш, свачији .

5.3. До међукатегоријалне антонимије, према нашим налазима, ретко долази услед лексичких празнина или хомографије и хомоформије, а чешће услед чињенице да се помоћу различитих врста речи може кодирати исти фрагмент стварности (нпр. леп - лепота - лепо), што је уочено и у ранијим истраживањима на енглеском језику (Фелбаум 1995; Бојева Омелечко и др. 2018), услед тога што се друге врсте речи могу употребити у придевском значењу (нпр. први, свој) или пак услед енкапсулације именичког значења у придев са којим често колоцира (нпр. штедљив често колоцира са особа, те у себе „усисава” то значење и почиње да значи штедљива особа. Стога се значењска супротност може успоставити са именицом расипник). Ипак, најчешће је међукатегоријална антонимија само привидна, будући да глаголски придеви и прилози процесом конверзије веома често постају придеви.

5.4. Тип дефиниције у РСЈ, који сугерише степен лексикализације придева, не одговара увек степену осамостаљења глаголских придева према подацима добијеним од испитаника (трпни придеви за које није успостављена одредница у РСЈ имају у својим асоцијативним-антонимским пољима подједнак број правих придева као и трпни придеви који су према лексикографима тек на путу лексикализације). Ипак, лексикографи понекад исправно уочавају да постоје случајеви који су се готово сасвим осамосталили у односу на одговарајући глагол, сигнализирајући то правим придевским дефиницијама (исп. обраду придева: компликован).

Уколико узмемо у обзир да је продуктивност трпних придева изразита (у овом истраживању чине $20 \%$ свих придевских лексема), постаје јасна лексикографска дилема да ли трпне придеве треба уносити у речник као засебне одреднице или не. (Истовремено, јасно је да далеко ређа лексикализација радних придева и глаголских прилога не поставља пред лексикографа исту дилему.) Из угла лексикографије има смисла бележити само новину у семантичком смислу (у односу на глаголску одредницу од које је придев настао), како би се уштедео

\footnotetext{
${ }^{10}$ Ову тврдњу могли бисмо поткрепити и тиме да када смо придеве задавали у одређеном виду, велики број испитаника одговоре је давао такође у одређеном виду.

${ }^{11}$ Исп. Станојчић/Поповић: 101, где се тврди да заменица свој може имати придевско значење.
} 
простор небележењем системске правилности. Из угла корисника, који није сигуран које одреднице треба сматрати правим придевима, неуспостављање одреднице сигнал је да не постоје потврде процеса лексикализације. Такође, када се на месту примарне дефиниције придева нађе граматичка дефиниција којом се упућује на одговарајући глагол и сва његова значења, остајемо у недоумици у ком значењу се дати придев најчешће јавља. У светлу скорог преласка на дигиталну верзију речника, аргумент уштеде простора више не би стајао, а до тог тренутка, уколико се успостављање придевских одредница чини сувишним, потврда лексикализације датог трпног придева могла би се бележити и у заглављу глаголске одреднице или на неки пригоднији начин. ${ }^{12}$ Игнорисање придевске природе трпних придева свакако је најлошија одлука.

5.5. Вративши се на почетак рада, рекли бисмо да се однос антонимије може успоставити и међу јединицама различитих врста речи, али када се из анализе искључе придеви настали конверзијом од глаголских облика, број преосталих међукатегоријалних антонима (са придевском врстом речи) готово је занемарљив ( $1,3 \%$ свих придевских антонима). Стога није чудно што за коренски тип језика (као што је енглески), овај феномен није уочен у асоцијативним тестовима, него тек претрагом великих корпусних база.

5.6. Сматрамо да би сакупљање, а потом и анализа овог, али и других типова лексичких односа преко онлајн платформи, на већем броју врста речи и стимулуса, пружило значајан допринос у одговарању на многа нерешена питања лексикологије и лексикографије.

\section{ЛИТЕРАТУРА}

Бабић ${ }^{2}$ 1991: S. Babić, Tvorba riječi u hrvatskom književnom jeziku, Zagreb: JAZU.

Бојева Омелечко и др. 2018: N. B. Boeva-Omelechko, M. R. Zheltukhina, O. P. Ryabko, G. G. Matveeva, E. V. Murugova and I. A. Zyubina, "Unusual Antonyms: Inter-Part-Of Speech Interaction in English Fictional Discourse", Space and Culture, India, 6 (4), 112-121.

Гортан Премк 2004: Д. Гортан-Премк, Полисемија и организаџија лексичког система у српскоме језику, Београд: Завод за уџбенике и наставна средства.

Драгићевић 2007: Р. Драгићевић, Лексикологија српског језика, Београд: Завод за уџбенике.

${ }^{12} \mathrm{O}$ неуједначености, али и предлозима уједначавања лексикографске обраде радног и трпног придева исп. Спасојевић 2013: 315-317, као и Јовановић 2013. 
Зипф 1949: G. K. Zipf, Human behavior and the principle of least effort, AddisonWesley Press.

Јакић 2016а: М. Јакић, Придевска антонимија у речнику, контексту и когнитивном систему, одбрањена докторска дисертација. (https:// nardus.mpn.gov.rs/handle/123456789/6202)

Јакић 2016б: М. Јакић, Страх је неопходан да бисмо били храбри, у: Р. Драгићевић (ур.), Речи под лупом, Београд: Танеси, 163-166.

Јакић Шимшић/Весић Павловић 2020: М. Јакић Шимшић, Т. Весић Павловић, Значењска супротност придева српског језика у реченичном контексту, Зборник Матице српске за филологију и лингвистику, $64,55-74$.

Јакић Шимшић/Шева, у припреми: М. Јакић Шимшић, Н. Шева, Асочијативни речник придевских антонима српског језика.

Јовановић 2013: Ј. Јовановић, Семантичка дивергентност трпног придева и његов третман у савременој лексикографији, у: С. Гудурић и М. Стефановић (ред.), Језици и културе у времену и простору, II/2, Нови Сад: Универзитет у Новом Саду, Филозофски факултет, 243-254.

Клајн 2003: И. Клајн, Творба речи у савременом српском језику. Други део. Суфиксачија и конверзија, Београд: Завод за уџбенике и наставна средства, Матица српска, Институт за српски језик САНУ.

Кристал 1985: D. Kristal, Enciklopedijski rečnik moderne lingvistike, Beograd: Nolit.

Лајонс 1977: J. Lyons, Semantics, Volume I, Cambridge, London, New York, Melbourne: Cambridge University Press.

Марфи 2003: M. L. Murphy, Semantic Relation and the Lexicon. Antonymy, Synonymy, and Other Paradigms, Cambridge University Press.

Палмер 1979: F. R. Palmer, Semantics, a new outline, Cambridge, London, New York, Melbourne: Cambridge University Press.

PCJ 2007: Речник српскога језика, Нови Сад: Матица српска.

Сосир 1989: F. de Sosir, Opšta lingvistika, Beograd: Nolit.

Спасојевић 2013: М. Спасојевић, О радном и трпном глаголском придеву са лексикографског аспекта, Научни састанак слависта у Вукове дане, 42/1, 309-319. 
Станојчић/Поповић 1999: Ж. Станојчић, Љ. Поповић, Граматика српскога језика за I, II, III, IV разред средње школе, Београд: Завод за уџбенике и наставна средства.

Taфpa 1998: B. Tafra, Konverzija kao gramatički i leksikografski problem, Filologija, 30-31, 349-361.

Упутства РСАНУ: Упутства за израду „Речника српскохрватског књижевног и народног језика САНУ”, Институт за српски језик [интерно издање].

Фелбаум 1995: C. Fellbaum, Co-Occuerrence and Antonymy, International Journal of Lexicography, 8(4), 281-303.

\section{INTER-PART-OF-SPEECH ANTONYMY IN CONTROLLED ASSOCIATION TASK}

\section{Summary}

Traditional linguistics states that only the same part of speech lexemes can constitute antonymy. However, several English language corpus investigations found evidence of the inter-part-of-speech antonymy, stating that no such evidence was found in associative task responses. We constructed The Associative Antonymy Dictionary of Serbian Language Adjectives, based on the controlled associations task, asking 158 participants to elicit antonyms for 394 presented adjective stimuli, and tried to find evidence from associative data of an inflected language, such as Serbian. Some of the stimuli originate from participles, but not all of them are lexicographically approved (in Dictionary of Serbian Language, DSL (=RSJ) 2007) to be lexicalized as adjectives. Furthermore, the type of a definition used in a lexicographic entry suggests a degree of lexicalization. Taking that into account, besides the traditional part-of-speech tagging, we also included four types of participles as annotates, and annotated both the stimuli and the answers that were given by at least three participants (64.276 answers). The aim of the study was to answer three questions: (1) what kind of a non-adjective associative-antonym answer was the most frequent in adjective associative-antonymous fields, (2) what kind of stimuli tended to attract a larger number of non-adjective answers and (3) what could be the possible reasons for that. The analysis showed that (1) the real adjective antonyms answers had the highest rate, and the second most frequent answers were participles, especially the passive participles. Also, (2) all the stimuli had the vast majority of real adjectives in associative-antonymous fields, which means that all of them function as real adjectives. Nevertheless, there were more non-adjective answers among participle-origin-adjectives than among the real ones, again most frequently of a passive participle origin. This could be explained by the previous result that participants in associative tests tended to give answers of the same inflective endings as stimuli. Finally, (3) potential reasons for non-adjective antonyms are less frequently lexical gaps or homography, and more frequently the fact that the same fragment of reality can be 
coded in different parts of speech, or an encapsulation of a noun meaning in the adjective that often co-occurre with it. The most frequent case is that inter-part-of-speech antonymy is just a pseudo-phenomenon, since the passive participles are productively becoming the real adjectives by the process of a conversion. In other words instead of inter-part-of-speech antonymy it is the way of enriching the adjective system of the Serbian language. Also, the comparison of a degree of lexicalization for adjectives, measured by two different criteria (types of definitions in DSL and the ratio of types of answers in associative-antonymous fields), shows that DSL does not always portray the lexicalization degree derived from knowledge of native speakers' competencies. Finally, excluding the lexicalized participles, remaining cases of inter-part-of-speech antonymy are relatively rare $(1.3 \%)$, so we can conclude that in the vast majority of cases antonymy is the lexical relation between same part-of-speech units.

Key words: antonym, oppositeness of meaning, associative dictionary, conversion, lexicalisation, lexicographic analysis of dictionary entries, passive participle, native speaker, quantitative analysis, paradigmatic/syntagmatic lexical relation. 